\title{
Foreign Language Anxiety in Student's Speaking and Writing Skills
}

(A Case Study of Undergraduate Students at Banten Jaya University)

\author{
DEDE ROHADI FAJRI \\ Universitas Banten Jaya \\ Serang, Indonesia \\ dederohadifajri@gmail.com
}

\begin{abstract}
The objective of this research was on the level of Foreign Language Anxiety that experienced by students. In this research, the researcher was use the Qualitative research as the method in implementing case study. The sources of data were 30 students of the second semester of Banten Jaya University. For collecting data that used in this study include classroom observation, questionnaires and interview. The questionnaire used to obtain specific information data was gathered from the participants by FLCAS of Horwitz et all (1986). From the result of FLCAS questionnaire, there were 10 students who felt very anxious with percentage $33.33 \%$, 8 students felt anxious with the percentage $26.67 \%, 8$ students felt mildly anxious with the percentage $26.67 \%$, 4 students felt relaxed with the percentage $13.33 \%$ and there was no student who felt very relaxed. Then, the result of WAT questionnaire were 7 students felt very anxious with percentage $23.33 \%, 8$ students felt anxious with the percentage $26.67 \%, 9$ students felt mildly anxious with the percentage $30 \%, 6$ students felt relaxed with the percentage $20 \%$ and there was no student who felt very relaxed. Based on the findings of the present study, several conclusions can be made: First, students' anxiety in speaking showed that the students never felt quite sure of themselves when they were speaking in foreign language class. Second, students' anxiety in writing above showed that most of students avoided writing in English.
\end{abstract}

Keywords: Foreign Language Anxiety, Speaking Skill, Writing Skill

\section{Introduction}

Research into the distinctive nature of FLA has found proof for its weakening effects on foreign acquisition. In terms of knowledge, anxious students were found to possess issue process pregnant input and to be less alert to language output (Krashen, 1981, p. 29). to boot, numerous levels of foreign language learners' achievements may well be influenced by motivation and anxiety. It is, therefore, important to explore the link between motivation and anxiety in terms of students' English learning action (Hao, M., Liu, M., and Hao, R. P., 2004, p. 93). Contrary to what happens abroad, fewer studies in Indonesia are conducted and acknowledged the results of tension on foreign learning. Just some empirical studies have touched on the supply of tension and centered on student's speaking skills. 
The previous studies found that almost all of the scholar's square measure sad in learning a distant language. The scholars feel annoyed, pressured, and nervous throughout some English categories. These uncomfortable feelings may be triggered by the instructor's attitudes or characteristics. the scholars suffer high levels of language anxiety in school once the lecturers square measure rigid, serious and authoritarian, or once students square measure ridiculed and humiliated by these grim lecturers.

On the opposite hand, students feel relaxed, motivated and fewer anxious once having the Gilbertian, easy-going, amiable and patient teacher's categories. Students would do their best and perform well in categories. These experiences demonstrate that there could be a particular degree of association between learner's foreign language anxiety and instructor's behaviors and personalities. Besides learner's variables like shallowness, beliefs, motivation, language proficiency so on, the present study makes an attempt to look at to what extent the academics influence student's foreign language anxiety as these feelings impede their ability to perform with success in English learning. Thus it's quite necessary to own Associate in Nursing investigation on foreign language anxiety level, determine the contributive factors, and determine foreign language speaking anxiety and writing anxiety that tough by students.

Anxiety is a feeling that affects everyone. Several factors will cause someone to expertise feelings of tension. Adults could expertise ANxiety caused by their jobs whereas students could expertise heightened levels of tension as a result of peer pressure or an imminent vital take a look at or project. English language learners, additionally as those students learning a remote language, expertise anxiety once it involves such room activities as speaking ahead of a gaggle of their fellow students or taking a take a look at during a language apart from their mother tongue (L1). English language learner students gift a specific set of 
issues that native speakers of English don't (Snyder, 2011, p. 1).

Horwitz et al separate Foreign Language Anxiety into 3 types of it. The primary is communication apprehension; it means the speaker feels uncomfortable once act with others. The second is taking a look at anxiety, it happens once students can face some tests or quizzes. Those mean that student is concern of failure within the take a look at. The last is concern of negative evaluations; this anxiety is fully fledged in any language-learning scenario, notwithstanding that language talent is employed. As a result of students notices that $\mathrm{s} / \mathrm{he}$ is evaluated by his/her teacher.

English language teaching is overcome with innumerous techniques and ways within the EFL schoolroom (Syafrizal, 2017, p. 66). the idea of Foreign Language Anxiety was initial given by Horwitz et al. in 1986 and describes FLA (Foreign Language Anxiety) as a definite variety of anxiety, cut loose alternative types of anxiety. Previous studies of tension had tried to relate to 3 types of anxiety one by one.
These square measure communication apprehension, take a look at anxiety, and concern of negative analysis (Elaine K. Horwitz, Michael B. Horwitz, Joann Cope, 1986, p. 125).

Anxiety is a feeling that affects all and sundry. Several factors will cause an individual to expertise feelings of hysteria. Adults could expertise anxiety caused by their jobs whereas students could expertise heightened levels of hysteria as a result of peer pressure or an close at hand vital check or project. West Germanic language learners, likewise as those students learning a far off language, expertise anxiety once it involves such room activities as speaking ahead of a bunch of their fellow students or taking a check in an exceedingly language aside from their tongue (L1). West Germanic language learner students gift a selected set of issues that native speakers of English don't (Snyder, 2011, p. 1).

Foreign Language Anxiety or a lot of exactly, Foreign Language room Anxiety (FLCA) is taken into account to be state of affairsal 
anxiety older within the well-defined situation of the foreign language room (MacIntyre \& Gardner, 1991a, 1991b, 1994). As such, Horwitz, Horwitz, and Cope (1991) read FLCA as "a distinct complicated of self-perceptions, beliefs, feelings, and behaviors associated with room acquisition arising from the individuality of the acquisition process". per Horwitz, Horwitz, and Cope (1991) potential causes of FLCA are communication apprehension, take a look at anxiety and worry of negative analysis. MacIntyre and Gardner (1991a) describe FLCA stemming from the negative expectations in foreign acquisition. On the opposite hand, found classroom-related factors to play a job in learners' developing FLCA, as cited in (Katalin, 2006, p. 40).

To satisfy completely different desires of analysis into anxiety, researchers classify anxiety into completely different classes. In line with Macintyre and Gardner (1991), anxiety may be understood from 3 categories: attribute anxiety, state anxiety, and situation-specific anxiety. A distinction may be created between the 3 classes that give necessary insight into our understanding of foreign or second language anxiety, as cited in (Nimat, 2013, p. 14).

\section{Method}

In this analysis, the research worker used the Qualitative analysis because the methodology in implementing case studies. Consistent with Sturman as cited in (Bassey, 1999, p. 26) 'Case study' could be a generic term for the investigation of a private, cluster or development. Whereas the techniques utilized in the investigation could also be varied and should embody each qualitative and quantitative approaches, the identifying feature of a case study is that the belief that human systems develop a characteristic wholeness or integrity and aren't merely a loose assortment of traits.

The sources of information were thirty students of the second semester of Banten Jaya University. Supported the researchers' expertise, the primary year in university was 
the toughest moment. as a result of within the 1st year, the scholars should be ready to adapt to a brand new atmosphere. thus the likelihood of tension is higher within the English learning method. For aggregation knowledge employed in this study embody schoolroom observation, questionnaires, and interview.

The research worker did the room observation to watch the event or method associated with the study and gaining implicit understanding, theory-in-use, and participants' purpose of read which could not most likely be explored by interview or form (Alwasilah, 2001).

In this case, the observation was done to look at the natural occurrences, the scholars were anxious once asked to return forward, nervous once being asked by the teacher, shame speaking ahead of the category, distressed concerning pronunciation, forgot country words once speaking, remained silent, got difficulties in fixing the tenses.

\section{FINDINGS AND DISCUSSION}

\section{Findings}

Based on the observation done on could fourth, 2018, by the scientist in speaking category of $2 \mathrm{~d}$ semester at English department of Banten Jaya University. From the observation, it had been renowned that the students' expression throughout speaking category is completely different. Most of the scholars showed that they were additional assured once the category was divided into some teams for doing the task given by the speaking the lecturer. they appear stress and worry if the lecturer asked them to try and do the task one by one.

It has happened as a result of they lack the boldness to provide oral explanations or arguments. it's happened as a result of they felt that they were lack of vocabulary and disable in victimization dictions, the simplest words to explain the case that they'd to argue. Many of them conjointly felt a scarcity of confidence as a result of they were afraid to be laughed by their friend once they were speaking, they felt that alternative students had 
additional ability than them. So, it created them keep, afraid and didn't

They just wished to follow the category with none contribution and saw their friend speak while not making an attempt to try and do identical things. It may be seen from their expression once the lecturer asked them to grant Associate in Nursing argument orally and singly, however on another hand, if they're divided into some cluster, they may need to mention something throughout the speaking category. provide a sensible job by giving arguments by one in every of the scholars in every cluster. From these things, it may be seen that several students had anxiety in English as a remote language for speaking. Questionnaire level used to categorize the anxiety level in speaking class was FLCAS, where the range scale was as follow:

\section{Table 1. Students' Anxiety Level in Speaking}

\begin{tabular}{|c|c|c|}
\hline $\begin{array}{c}\text { Level Of } \\
\text { Anxiety }\end{array}$ & $\begin{array}{c}\text { Total } \\
\text { Respondent }\end{array}$ & Percentage \\
\hline Very Anxious & 10 & $33.33 \%$ \\
\hline Anxious & 8 & $26.67 \%$ \\
\hline $\begin{array}{c}\text { Mildly } \\
\text { Anxious }\end{array}$ & 8 & $26.67 \%$ \\
\hline Relaxed & 4 & $13.33 \%$ \\
\hline Very Relaxed & 0 & $0 \%$ \\
\hline Total & $\mathbf{3 0}$ & $\mathbf{1 0 0} \%$ \\
\hline
\end{tabular}

From the result of questionnaire in table 1 above, there were 10 students who felt very anxious with percentage $33.33 \%, 8$ students felt anxious with the percentage $26.67 \%, 8$ students felt mildly anxious with the percentage $26.67 \%, 4$ students felt relaxed with the percentage $13.33 \%$ and there was no student who felt very relaxed. 
The researcher drew the diagram of anxiety level of speaking below:

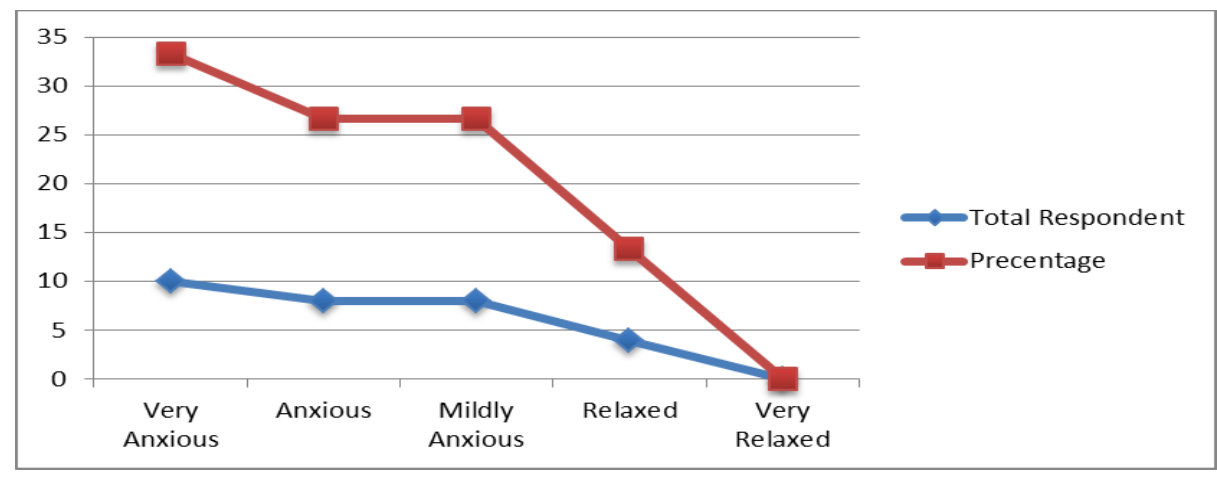

Figure 1. The Diagram of Student's Anxiety Level of Speaking

Questionnaire level used to categorize the anxiety level in writing class was same as speaking class, where the level used was WAT, and range scale was as follow:

Table 2: Students' Anxiety Level in Writing

\begin{tabular}{|c|c|c|}
\hline Level Of Anxiety & $\begin{array}{c}\text { Total } \\
\text { Respondent }\end{array}$ & Percentage \\
\hline Very Anxious & 7 & $23.33 \%$ \\
\hline Anxious & 8 & $26.67 \%$ \\
\hline Mildly Anxious & 9 & $30 \%$ \\
\hline Relaxed & 6 & $20 \%$ \\
\hline Very Relaxed & 0 & $0 \%$ \\
\hline Total & $\mathbf{3 0}$ & $\mathbf{1 0 0} \%$ \\
\hline
\end{tabular}

From the result of 26.67\%, 9 students felt mildly questionnaire in table 2 above, there were 7 students felt very anxious anxious with the percentage $30 \%, 6$ with percentage $23.33 \%, 8$ students students felt relaxed with the felt anxious with the percentage percentage $20 \%$ and there was no student who felt very relaxed. 
The researcher drew the diagram of anxiety level below:

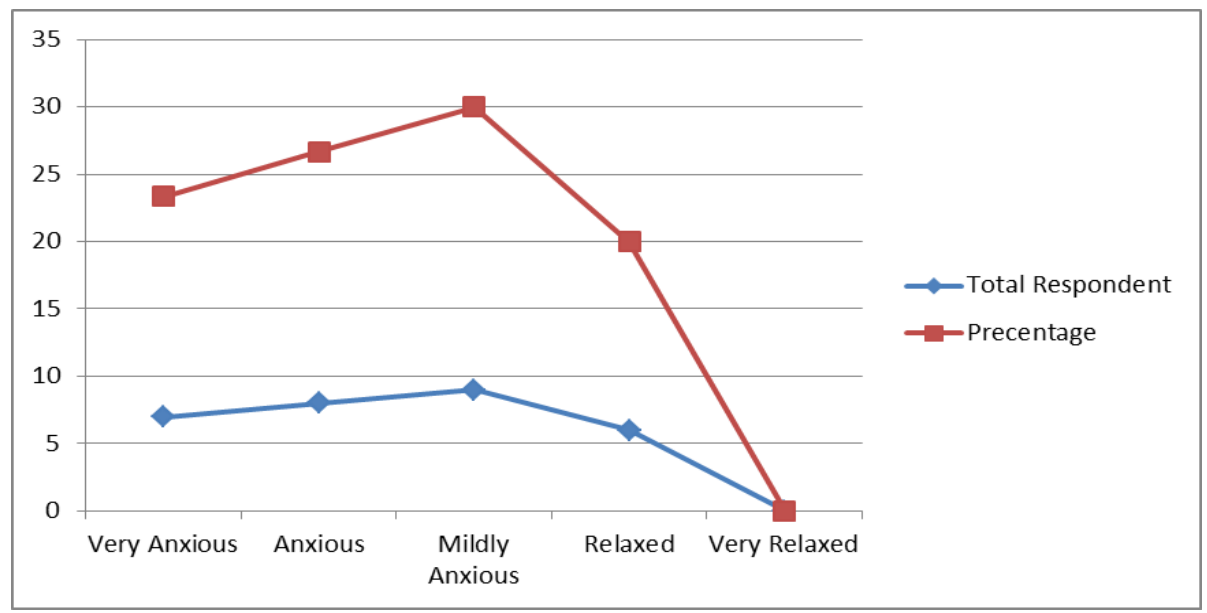

Figure 2. The Diagram of Student's Anxiety Level in Writing 
Interview was done at May 25th 2018 with five students of English Department at Banten Jaya University. Interview was done to know about students' response related anxiety they felt in speaking and writing class.

From those queries interview, the scholars answered that they felt nervous to produce any presentation, assignment. They felt affronted once somebody affronted or laughed at them before of someone once they spoke in English. Since of that, they forgot what to mention and got blank once they had to talk before of the category. So, their mind got blank if their academics asked them to mention one thing in English. Finally, they couldn't speak fluently.

Then, the teacher spoke too quickly once the speaking category was happening, they couldn't perceive what the teacher same. It created them thus confuses and tried arduous to follow the activity well. They needed the teacher to encourage them so as to be smart at speaking English. For them, generally the teacher created them chilling. But, the teacher is rarely to talk in English whereas within the speaking category. It affected abundant for them, so that they couldn't get pleasure from the educational method well. Moreover, they didn't like if the teacher asked the materials that they hadn't ready.

Hence, the scholar was aforementioned that the supply of tension was in descriptive linguistics. There have been several English grammatical rules, it created them terribly confused. That's why they may not speak in English with none hesitation. Not solely that, after they spoke in English before of another person or their friend, then suddenly they didn't keep in mind the vocabulary. it absolutely was one in every of the sources of their anxiety. They conjointly educated that their vocabulary isn't therefore sturdy. For them, vocabulary is one in every of the necessary elements after they had to talk particularly before of the many folks, that they had to be in a position in exploitation smart vocabulary or diction so as to create them be brave as a result of their statement would be supported by appropriate vocabularies. That's why they felt confused to mention what they needed to speak regarding.

\section{Discussions}

Regarding the first analysis question, the investigator got the extent of students' anxiety from the form that was given to the scholars on eleventh could 2018. From the results of the form, there have been ten 
students WHO felt terribly anxious with proportion thirty three.33\%, eight students felt anxious with the share twenty six.67\%, eight students felt gently anxious with the share twenty six.67\%, four students felt relaxed with the share thirteen. $33 \%$ and there was no student WHO felt terribly relaxed.

The data gotten was supported by the results of observation. The information showed that for many the scholars, anxiety fazed them in the least to require additional foreign language categories. Throughout language category, they found themselves considering things that had nothing to try and do with the course. They solely unbroken thinking that the opposite students were higher at languages.

Some of them felt difficult during tests in the language class. Since, the more they studied for a language test, the more confused I got. It could be seen when they were panic to speak without preparation, when the language teacher asked questions which they hadn't prepared in advance. Even if they were well prepared for language class, they felt anxious about it, because they felt pressure to prepare very well. It was happened when the teacher asked them to speaking the foreign language in front of other students. So, it made them very self- conscious. They were afraid that the other students would laugh at them when they spoke.

Moreover, they were seen nervous, they forgot things they knew. So, it embarrassed them to volunteer answers. They were conjointly got upset after they did not perceive what the teacher was correcting. Anxiety conjointly happened once language category captive thus quickly, and that they did not perceive each word the language teacher aforesaid and create them felt distressed concerning obtaining left behind. It created them a lot of tense, nervous and confused. They felt powerless by the quantity of rules that that they had to find out to talk a remote language.

But on the opposite hand, once they were on their thanks to language category, they felt terribly positive and relaxed. They might conjointly in all probability felt comfy around native speakers of the foreign language. Since they felt once they act with natives, it wouldn't create them therefore nervous and embrace as a result of natives would perceive why they did a slip, and that they believed they natives can teach them concerning the way to speak well while not happy at them owing to the mistakes they did in speaking. 
Regarding the $2 \mathrm{~d}$ analysis question, the man of science got the extent of students' anxiety from the form that given to the scholars on might eighth, 2018, there have been seven students felt terribly anxious with share twenty three.33\%, eight students felt anxious with the proportion twenty six.67\%, nine students felt gently anxious with the proportion half-hour, vi students felt relaxed with the proportion 2 hundredth and there was no student WHO felt terribly relaxed.

The data showed that in students' mind, they gave the impression to go blank once they began to work on a composition in English, particularly once they had handy in a very composition in English, they looked confuse to seem forward to writing down the concepts.

Just many of them World Health Organization liked to write down the concepts and felt assured in their ability clearly expressed their concepts once writing in English. It may be seen from their interest, simply two hundredth of \{the total|the entire|the World Health Organizationle|the full|the overall $\}$ range of respondents who felt relaxed and enjoyed causing English writing to magazines for analysis and publication, they liked to possess their friends browse what that they had written in English. Since they additionally felt that some folks appeared to fancy what they wrote in English and that they felt fancy too in writing in English as a result of it had tons of fun. They additionally liked seeing their thoughts on paper in English. For these very little students, discussing my English writing with others is a pleasant expertise.

On the opposite hand, for many of them, expressing ideas through writing in English looks to be a waste of your time, particularly once they felt nervous regarding writing. They felt that they ne'er appeared to be ready to clearly write down their ideas and did poorly in English composition categories. they'd a terrible time organizing my ideas in Associate in Nursing English composition course. Once they handed in Associate in Nursing English composition they knew that they were about to do poorly, as a result of for them, wrote smart compositions in English was therefore tough. It happened as a result of they didn't like English compositions to be evaluated and that they weren't smart at writing in English.

In this study, from the observations and interviews, it's found that there square measure 2 sorts of foreign language anxiety i.e. attribute anxiety and state/situational 
anxiety. Each sorts of anxieties occurred on the scholars once they had to perform speaking \& writing tasks.

On the opposite hand, there are 3 main sources of foreign language anxiety that the scientist detected from the study; communication apprehension, take a look at anxiety, and worry of negative analysis.

\section{CONCLUSIONS AND SUGGESTIONS}

\section{Conclusions}

Based on the findings of the present study, several conclusions can be made:

First, students' anxiety in speaking showed that the scholars ne'er felt quite positive of themselves once they were speaking in exceedingly foreign language categories. It is seen from the students' activity within the room.

Second, students' anxiety in writing higher than showed that the majority of the scholars avoided writing in English. They were terrified of writing essays in English once they knew it might be evaluated, and that they felt worry of their English writing being evaluated.

Third, from the observations and interviews, it's found that there are a unit 2 styles of foreign language anxiety i.e. attribute anxiety and state/situational anxiety. Each styles of anxieties occurred on the scholars once they had to perform speaking \& writing tasks. There area unit 3 main sources of foreign language anxiety that the man of science detected from the study; communication apprehension, check anxiety, and worry of negative analysis.

\section{Suggestions}

So knowing that foreign language anxiety exists which it will have negative effects on the training method, what will we tend to do as academics to scale back it and therefore increase student engagement within the classroom? The primary step is to easily bear in mind of the chance of learning anxiety. The scholars sitting within the back row not speech communication something might not be bored or impartial or unmotivated; rather they may simply be terribly anxious. We'd be able to facilitate these students achieve learning the language if we will scale back their anxiety.

For anxiety stemming from learner characteristics, lecturers ought to have students acknowledge their irrational beliefs and fears through activities designed for this purpose. Lecturers ought to additionally advocate that extremely anxious students participate in some kind of supplemental instruction, like obtaining individual 
tutoring (from the teacher and/or advanced language students) or connection a language club. Additional exposure to the language, outside of the room, could facilitate anxious students become lighter with the language and so facilitate cut back anxiety.

\section{References}

Alwasilah, A. C. (2001). Perspektif Pendidikan Bahasa Inggris di Indonesia dalam Konteks Persaingan Global. Bandung: $C V$. Andira.

Bassey, M. (1999). Case Study Research in Educational Settings. Buckingham. Philadelphia: Open University Press.

Elaine K. Horwitz, Michael B. Horwitz, Joann Cope. (1986). Foreign Language Classroom Anxiety. The Modern Language Journal, Vol. 70, 125-132.

Hao, M., Liu, M., and Hao, R. P. (2004). An empirical study on anxiety and motivation in English. Asian Journal of English Language Teaching, 14, 89104.

Krashen, S. (1981). Second language acquisition and second language learning. New York: Prentice Hall.

Nimat, N. (2013). An Investigation of English Language Anxiety.
Dissertation Submitted to the Department of English and Humanities of BRAC University, 1-92.

Snyder, G. W. (2011). How Anxiety Affects Second Language Aquisition of High School

Students. https://dspace.sunyconnect.suny.edu, $1-52$.

Syafrizal, \& Rahmawati, C., (2017). Teacher's Speaking Strategies at Vocational High School. The Journal of English Studies, 66-83. 
